\title{
Propagation of citrus somatic hybrids with potential for utilization as rootstocks
}

Rafael PIO ${ }^{a}$, Francisco de Assis Alves MoURÃo FILHO ${ }^{b *}$, Beatriz Madalena Januzzi MENDES ${ }^{c}$, Fábio Albuquerque ENTELMANN ${ }^{b}$, André Siqueira Rodrigues ALVES ${ }^{\text {b }}$

\begin{abstract}
a Instituto Agronômico (IAC), Centro Avançado de Pesquisa Tecnológica do Agronegócio de Frutas, Av. Luiz Pereira dos Santos, $n^{\circ} 1500$, Corrupira, 13214-820, Jundiaí, SP, Brazil

${ }^{\mathrm{b}}$ Departamento de Produção Vegetal, USP/ESALQ, CP 9, Piracicaba, SP, 13418-900, Brazil

famourao@esalq.usp.br
\end{abstract}

${ }^{\mathrm{C}}$ Laboratório de Biotecnologia Vegetal, USP/CENA, CP 96, Piracicaba, SP, 13400-970, Brazil

* Correspondence and reprints

Received 1 March 2005 Accepted 23 September 2005

Fruits, 2006, vol. 61, p. 1-7 (c) 2006 Cirad/EDP Sciences All rights reserved DOI: 10.1051/fruits:2006001

RESUMEN ESPAÑOL, p. 7
Propagation of citrus somatic hybrids with potential for utilization as rootstocks.

Abstract - Introduction. Alternative propagation techniques must be developed in order to reduce the time required to evaluate germplasm in citrus breeding programs. Our study investigated the rooting capacity and initial plant development of different citrus somatic hybrids that have potential for use as rootstocks. Materials and methods. Eleven different hybrids were tested. Cuttings of these plants were placed in trays inside an intermittent mist chamber. After 100 days, the percentage of cuttings with callous and with roots, average number of roots, and root length were recorded. The cuttings were then transferred to plastic bags and kept in the greenhouse. The flush length was recorded monthly. After 7 months, the percentage of plants suitable for grafting and the average scion and root dry mass were calculated. Results and discussion. [Caipira sweet orange + Cleopatra mandarin], [Caipira sweet orange + Volkamer lemon], [Rangpur lime + Sunki mandarin] and [Rohde Red Valencia sweet orange + Volkamer lemon] hybrids developed many roots, while [Caipira sweet orange + Volkamer lemon] and [Rohde Red Valencia sweet orange + Volkamer lemon] hybrids showed the best development after the transplant.

\section{Brazil / Citrus sp. / protoplast fusion / cuttings / rooting}

\section{Propagation d'hybrides somatiques d'agrumes utilisables comme porte- greffes.}

Résumé - Introduction. De nouvelles techniques de propagation doivent être développées pour réduire le temps requis pour évaluer le germplasm des agrumes dans des programmes d'amélioration. Nous avons étudié la capacité à s'enraciner et le début du développement de différents hybrides somatiques d'agrumes qui pourraient être utilisés comme porte-greffes. Matériel et méthodes. Onze hybrides somatiques d'origine diverses ont été utilisés. Des boutures de plants ont été placées dans des plateaux à l'intérieur d'une chambre à brumisation intermittente. Après 100 jours de culture, le pourcentage des boutures présentant des cals et des racines, le nombre moyen de racines et la longueur des racines formées ont été enregistrés. Les boutures ont été alors transférées dans des sacs en plastique et maintenues en serre chaude. La longueur des pousses a été enregistrée mensuellement. Après 7 mois, le pourcentage de plants aptes à être greffés et la masse sèche moyenne de scions et de racines ont été calculés. Résultats et discussion. Les hybrides somatiques [oranger Caipira + mandarinier Cleopatre], [oranger Caipira + citronnier Volkamer], [limier Rangpur + mandarinier Sunki] et [oranger Rohde Red Valencia + citronnier Volkamer] ont développé de nombreuses racines, alors que les hybrides [oranger Caipira + citronnier Volkamer] et [oranger Rohde Red Valencia + citronnier Volkamer] ont montré le meilleur développement après repiquage en sacs.

Brésil / Citrus sp. / fusion de protoplastes / bouture / enracinement 
Table I.

Origin of 11 citrus somatic hybrids tested for their utilization as rootstocks (USP/ESALQ, Piracicaba-SP, Brazil, 2004).

\begin{tabular}{lllll} 
& \multicolumn{1}{c}{ Somatic hybrid } \\
Common name & \multicolumn{1}{c}{ Species } & Common name & \multicolumn{1}{c}{ Species } \\
\hline Rangpur lime & (Citrus limonia L. Osbeck) + Sour orange & (C. aurantium L.) \\
Caipira sweet orange & (C. sinensis L. Osbeck) & + Rangpur lime & (C. limonia L. Osbeck) \\
Caipira sweet orange & (C. sinensis L. Osbeck) & + Cleopatra mandarin & (C. reticulata Blanco) \\
Caipira sweet orange & (C. sinensis L. Osbeck) & + Volkamer lemon & (C. volkameriana Pasquale) \\
Caipira sweet orange & (C. sinensis L. Osbeck) & + Rough lemon & (C. jambhiri Lushington) \\
Cleopatra mandarin & (C. reticulata Blanco) & + Volkamer lemon & (C. volkameriana Pasquale) \\
Cleopatra mandarin & (C. reticulata Blanco) & + Sour orange & (C. aurantium L.) \\
Rangpur lime & (C. limonia L. Osbeck) & + Sunki mandarin & (C. sunki Hort. ex. Tanaka) \\
Ruby Blood sweet orange & (C. sinensis L. Osbeck) & + Volkamer lemon & (C. volkameriana Pasquale) \\
Rohde Red Valencia sweet orange & (C. sinensis L. Osbeck) & + Volkamer lemon & (C. volkameriana Pasquale) \\
Valencia sweet orange & (C. sinensis L. Osbeck) & + & - & Fortunella obovata
\end{tabular}

\section{Introduction}

Citrus plants are commercially propagated by grafting onto rootstocks that have the capacity to induce desirable characteristics in the scion such as fruit quality and resistance to biotic and abiotic factors.

Despite the great genetic variability among citrus and other genera in the Rutaceae family, conventional breeding programs have limitations to developing new rootstock cultivars. This is due especially to the barriers related to citrus reproductive biology such as nucelar embryony, polyembryony, high heterozygosity, pollen and ovule sterility, sexual incompatibility and juvenility [1]. Thus, most of the citrus cultivars developed around the world during this last century have been selected from mutations and natural selections.

The development of biotechnological techniques, associated with conventional breeding, has made it possible to overcome some of the natural barriers in citrus breeding and has led to the development of cultivars with superior qualities. Among the biotechnological tools applied in citrus breeding, protoplast fusion has presented great potential by producing somatic hybrids (allotetraploids). These hybrids maintain the complex genetic combination from both parents and there is no meiotic segregation characterized by the associated expression of dominant characteristics [2]. The production of interspecific and intergeneric somatic hybrids in citrus through protoplast fusion may result in the production of more promising rootstocks. It is possible to combine the desired characteristics from two separate species into the new hybrid.

Adequate propagation of new somatic hybrids is very important in order to evaluate both the agronomic potential and the commercial use. Propagation through cuttings is an asexual method of multiplication that enables retention of characteristics from the mother plant and a rapid increase in the number of plants [3]. In studies that involve the characterization of citrus genotypes regarding the resistance and tolerance to biotic and abiotic factors, it is very important that in each genotype studied there is no genetic variability that could result in erroneous conclusions. Also, high coefficients of variation may be observed in this kind of study, especially in investigations that involve pathogens [4], because plants grown from seed can be originated from zygotic embryos [5]. Considering the long juvenile period of citrus, it is essential to select fast vegetative propagation methods to evaluate these new genetic materials; many species can take 
more than five years before the first production [6]. The objective of this study was to evaluate the rooting capacity of cuttings and the initial development of 11 citrus somatic hybrids with potential for utilization as rootstocks.

\section{Materials and methods}

Plants of 11 citrus somatic hybrids (table I) [7-9] cultivated in pots were selected for this study. This material was kept in an aphidproof screen-house under 50\% shade-screen. The plants were submitted to medium-severe pruning in order to stimulate new sprouting. After 6 months, 15-cm-long cuttings, with at least three buds and two leaves, were collected from each plant. The leaves were cut to half of the original size. The base of each cutting was treated with indolbutyric acid (IBA) $\left(1000 \mathrm{mg} \cdot \mathrm{L}^{-1}\right)$ for $10 \mathrm{~min}$. Then, the cuttings were individually placed in 72-cell (cell capacity $=120 \mathrm{~cm}^{3}$ ) expanded polystyrene trays filled with Plantmax Citrus ${ }^{\mathrm{TM}}$ potting mix.

The experimental design was randomized complete block with 11 treatments (somatic hybrids) and four replications, each experimental unit comprised of 18 cuttings. The cuttings were maintained inside an intermittent mist chamber $\left[(25 \pm 5){ }^{\circ} \mathrm{C}, 72 \%\right.$ relative humidity, spraying time of $20 \mathrm{~s}$ with 10-min intervals] for 100 days. After 100 days, the average number of roots, and root length for each plant and the percentage of cuttings with callous and with roots were recorded.

After this evaluation, 40 cuttings from each somatic hybrid were selected and transferred to plastic bags $[(35 \times 20) \mathrm{cm}, 5 \mathrm{~L}]$, containing Rendmax Citrus ${ }^{\mathrm{TM}}$ commercial potting mix, and kept in a greenhouse. Plants were watered daily. Only one sprout per cutting was selected, 15 days after transplanting, in order to promote a single stem. One month after the transplant, weekly fertilizing with calcium nitrate $(15.5 \% \mathrm{~N}$ and $19 \% \mathrm{Ca}), 0.84 \mathrm{~g} \cdot \mathrm{L}^{-1}$ Kristalon Hydro ${ }^{\mathrm{TM}}(20 \%$ N, $8 \% \mathrm{P}_{2} \mathrm{O}_{5}, 8 \% \mathrm{~K}_{2} \mathrm{O}, 2 \% \mathrm{MgO}, 0.025 \% \mathrm{~B}$, $0.01 \% \mathrm{Cu}, 0.07 \% \mathrm{Fe}, 0.04 \% \mathrm{Mn}, 0.004 \% \mathrm{Mo}$ and $0.025 \% \mathrm{Zn}$ ) and $0.08 \mathrm{~g} \cdot \mathrm{L}^{-1}$ Tenso Iron Hydro $^{\mathrm{TM}}(6 \% \mathrm{Fe})$ was started. The seedlings were pruned periodically to maintain their growth in single stems.

The flush length was recorded monthly for 7 months. The flush measurements were concluded when $50 \%$ of plants of at least one somatic hybrid were ready to be grafted. At that time, the percentage of plants suitable for grafting (diameter greater than $0.65 \mathrm{~cm}$ ) and average scion and root dry mass were calculated for all plants. The experimental design was of randomized blocks with 11 treatments (somatic hybrids), seven subplots (months), four replications and 10 cuttings per plot.

\section{Results and discussion}

\subsection{Characteristics of rooted cuttings}

[Caipira sweet orange + Rangpur lime], [Caipira sweet orange + Cleopatra mandarin], [Caipira sweet orange + Volkamer lemon], [Caipira sweet orange + Rough lemon], [Rangpur lime + Sunki mandarin], [Rohde Red Valencia sweet orange + Volkamer lemon] and [Valencia sweet orange + Fortunella obovata] somatic hybrids yielded the greatest percentage of root formation (table II). [Cleopatra mandarin + Volkamer lemon] hybrid yielded an intermediate amount and [Rangpur lime + sour orange], [Cleopatra mandarin + sour orange] and [Ruby Blood sweet orange + Volkamer lemon] hybrids yielded the least amount of roots. Comparing the percentage of rooted cuttings with the percentage of cuttings with callous, a strong correlation was observed, demonstrating that the hybrids that showed high rooting capacity also showed high callous induction. [Cleopatra mandarin + sour orange] hybrid was the exception (table II).

Root formation in the cuttings was a response to the trauma produced by the cut at the base of the cutting. With the wound caused by the cut, a trauma in the xylem and phloem tissues occurs, followed by a cicatrization process with suberins responsible for the decrease in dehydration in the wounded area [10]. In this region, very often a disorganized cell mass called callous is 


\section{R. Pio et al.}

Table II.

Percentage of rooted cuttings, percentage of cuttings with calli, average number of roots emitted from the cuttings and average root length of 11 citrus somatic hybrids tested for their utilization as rootstocks (USP/ ESALQ, Piracicaba-SP, Brazil, 2004).

\begin{tabular}{|c|c|c|c|c|}
\hline Somatic hybrid & $\begin{array}{l}\text { Rooted cuttings } \\
\text { (\%) }\end{array}$ & $\begin{array}{l}\text { Cuttings with calli } \\
\text { (\%) }\end{array}$ & No. of roots emitted & $\begin{array}{l}\text { Average root length } \\
(\mathrm{cm})\end{array}$ \\
\hline Rangpur lime + sour orange & $53.0 \mathrm{c}$ & $75.0 \mathrm{~b}$ & $3.5 \mathrm{~b}$ & $2.1 \mathrm{~d}$ \\
\hline Caipira sweet orange + Rangpur lime & $93.0 \mathrm{a}$ & $97.0 \mathrm{a}$ & $2.7 \mathrm{~b}$ & $3.6 \mathrm{~b}$ \\
\hline Caipira sweet orange + Cleopatra mandarin & $100.0 \mathrm{a}$ & $100.0 \mathrm{a}$ & $2.8 \mathrm{~b}$ & $4.2 \mathrm{a}$ \\
\hline Caipira sweet orange + Volkamer lemon & $92.7 \mathrm{a}$ & $97.2 \mathrm{a}$ & $4.2 \mathrm{a}$ & $3.6 \mathrm{~b}$ \\
\hline Caipira sweet orange + Rough lemon & $98.5 \mathrm{a}$ & $100.0 \mathrm{a}$ & $2.9 \mathrm{~b}$ & $3.6 \mathrm{~b}$ \\
\hline Cleopatra mandarin + Volkamer lemon & $72.2 \mathrm{~b}$ & $80.5 \mathrm{~b}$ & $4.7 \mathrm{a}$ & $3.8 \mathrm{~b}$ \\
\hline Cleopatra mandarin + sour orange & $54.2 \mathrm{c}$ & 92.7 a & $3.3 \mathrm{~b}$ & $1.6 \mathrm{~d}$ \\
\hline Rangpur lime + Sunki mandarin & $87.5 \mathrm{a}$ & 95.7 a & $4.5 \mathrm{a}$ & $2.9 \mathrm{c}$ \\
\hline Ruby Blood sweet orange + Volkamer lemon & $52.7 \mathrm{c}$ & $76.5 \mathrm{~b}$ & $2.5 \mathrm{~b}$ & $3.4 \mathrm{~b}$ \\
\hline Rohde Red Valencia sweet orange + Volkamer lemon & $98.5 \mathrm{a}$ & $100.0 \mathrm{a}$ & $2.6 \mathrm{~b}$ & $4.8 \mathrm{a}$ \\
\hline Valencia sweet orange + Fortunella obovata & $88.6 \mathrm{a}$ & $98.0 \mathrm{a}$ & $3.3 \mathrm{~b}$ & $2.1 \mathrm{~d}$ \\
\hline Coefficient of variation (\%) & 9.45 & 7.30 & 16.2 & 14.6 \\
\hline
\end{tabular}

formed. The existence of callous in the roots may be correlated to root formation and, although they are two independent events, both tissue types need identical conditions in order to be formed [11].

[Caipira sweet orange + Volkamer lemon], [Cleopatra mandarin + Volkamer lemon] and [Rangpur lime + Sunki mandarin] hybrids resulted in the highest number of roots per cutting. Regarding root length, only [Caipira sweet orange + Cleopatra mandarin] and [Rohde Red Valencia sweet orange + Volkamer lemon] hybrids with average root length of $4.2 \mathrm{~cm}$ and $4.8 \mathrm{~cm}$, respectively, presented significantly higher values than the other hybrids $(P \leq 0.01)$ (table II).

In general, somatic hybrids presented high rooting potential, occurring with more than $87.5 \%$ of cuttings in some cases. This fact has also been reported by other authors, where the [Citrus deliciosa + Poncirus trifoliata] somatic hybrid yielded root formation in approximately $90 \%$ of cuttings [12]. Related research on other somatic hybrid combinations also revealed that cuttings treated with NAA or IBA produced greater numbers of roots that were longer and thicker than those of the control. However, the effect of varying concentrations of these plant regulators on rooting was not uniform for all of the experimental clones [13]. On the other hand, the rootstocks utilized in citrus production have not shown a high percentage of rooting, for example that for 'Volkamer' lemon (65.9\%), 'Rangpur' lime (60.3\%), 'Swingle' citrumelo (48.3\%), 'Sunki' mandarin (11.3\%) and Poncirus trifoliata (13.6\%) [14-16]. Sweet orange scion cultivars, such as 'Pera' and 'Valencia', have shown even lower rooting [(3.8 and 1.5)\%, respectively], as opposed to 'Sicilian' lemon and 'Tahiti' lime [(77.9 and 83)\% respectively] [16-18].

The differences in the rooting potential between the somatic hybrids and the other citrus cultivars could be associated with the fact that the hybrids came from juvenile material; the cuttings were taken from plants that had not reached the reproductive phase. Juvenility may have played an important role in this process due to higher capacity to have adventitious roots induced in juvenile tissue [19]. Another factor that could have increased the root formation in somatic hybrids in this study was the pruning done 
Table III.

Average flush length $(\mathrm{cm})$ of 11 citrus somatic hybrids after their transplant to plastic bags containing Rendmax Citrus $^{\text {TM }}$ commercial potting mix (USP/ESALQ, Piracicaba-SP, Brazil, 2004).

\begin{tabular}{|c|c|c|c|c|c|c|c|}
\hline \multirow[t]{2}{*}{ Somatic hybrid } & \multicolumn{7}{|c|}{ Days after transplanting } \\
\hline & 30 & 60 & 90 & 120 & 150 & 180 & 210 \\
\hline Rangpur lime + sour orange & $3.7 \mathrm{Bb}$ & $4.8 \mathrm{Bc}$ & $5.1 \mathrm{Bd}$ & $5.3 \mathrm{Be}$ & $5.2 \mathrm{Bd}$ & 7.2 Ad & $10.0 \mathrm{Ae}$ \\
\hline Caipira sweet orange + Rangpur lime & 4.3 Eb & 8.8 Db & $11.4 \mathrm{Cc}$ & $12.0 \mathrm{Cc}$ & $15.6 \mathrm{Bb}$ & $27.3 \mathrm{Ab}$ & $28.8 \mathrm{Ac}$ \\
\hline Caipira sweet orange + Cleopatra mandarin & 4.7 Db & 8.1 Db & $11.1 \mathrm{Cc}$ & $11.7 \mathrm{Cc}$ & $14.7 \mathrm{Cb}$ & $27.1 \mathrm{Bb}$ & $30.8 \mathrm{Ac}$ \\
\hline Caipira sweet orange + Volkamer lemon & 7.9 Ea & $13.5 \mathrm{Da}$ & $18.0 \mathrm{Ca}$ & $18.8 \mathrm{Ca}$ & $20.4 \mathrm{Ca}$ & $32.5 \mathrm{Ba}$ & $43.0 \mathrm{Aa}$ \\
\hline Caipira sweet orange + Rough lemon & $5.5 \mathrm{~Eb}$ & $9.9 \mathrm{Da}$ & $13.4 \mathrm{Cb}$ & $15.9 \mathrm{Cb}$ & $20.5 \mathrm{Ba}$ & $30.9 \mathrm{Aa}$ & 33.3 Ac \\
\hline Cleopatra mandarin + Volkamer lemon & 7.3 Ea & 12.1 Da & $17.8 \mathrm{Ca}$ & $18.5 \mathrm{Ca}$ & $20.7 \mathrm{Ca}$ & $33.9 \mathrm{Ba}$ & $38.6 \mathrm{Ab}$ \\
\hline Cleopatra mandarin + sour orange & $2.6 \mathrm{Bb}$ & $3.8 \mathrm{Bc}$ & $6.1 \mathrm{Ad}$ & $6.0 \mathrm{Ae}$ & $6.6 \mathrm{Ad}$ & 7.8 Ad & $10.1 \mathrm{Ae}$ \\
\hline Rangpur lime + Sunki mandarin & $6.4 \mathrm{Fa}$ & $11.4 \mathrm{Ea}$ & 14.3 Db & $15.2 \mathrm{Db}$ & $19.1 \mathrm{Ca}$ & $31.7 \mathrm{Ba}$ & $36.9 \mathrm{Ab}$ \\
\hline Ruby Blood sweet orange + Volkamer lemon & $3.9 \mathrm{Cb}$ & $7.3 \mathrm{Bb}$ & $9.2 \mathrm{Bc}$ & $9.0 \mathrm{Bd}$ & $9.9 \mathrm{Bc}$ & $18.8 \mathrm{Ac}$ & $21.5 \mathrm{Ad}$ \\
\hline Rohde Red Valencia sweet orange + Volkamer lemon & 8.5 Ea & $11.5 \mathrm{Ea}$ & 17.1 Da & 18.8 Da & $23.2 \mathrm{Ca}$ & $34.6 \mathrm{Ba}$ & $44.7 \mathrm{Aa}$ \\
\hline Valencia sweet orange + Fortunella obovata & $4.2 \mathrm{Cb}$ & $6.7 \mathrm{Cb}$ & $8.0 \mathrm{Cd}$ & $8.6 \mathrm{Cd}$ & $11.7 \mathrm{Bc}$ & 16.7 Ac & 18.6 Ad \\
\hline
\end{tabular}

in the stock plants before taking the cuttings in order to stimulate new growth. In mature plants, from species with low rooting capacity, it could be useful to induce new growth in order to increase this potential to form more roots [20].

\subsection{Flush length of somatic hybrids}

Within 30 days after transplanting, [Caipira sweet orange + Volkamer lemon], [Cleopatra mandarin + Volkamer lemon], [Rangpur lime + Sunki mandarin] and [Rohde Red Valencia sweet orange + Volkamer lemon] hybrids were those which presented the greatest flush length (table III). It can be pointed out that the same hybrids yielding the best results in the first evaluation were the ones that stood out at the end of the study. However, [Caipira sweet orange + Volkamer lemon] and [Rohde Red Valencia sweet orange + Volkamer lemon] hybrids yielded the longest flush length [(43.0 and 44.7) $\mathrm{cm}$, respectively] followed by the [Cleopatra mandarin + Volkamer lemon] and [Rangpur lime + Sunki mandarin] hybrids
[(38.6 and 36.9) cm, respectively]. [Rangpur lime + sour orange] and [Cleopatra mandarin + sour orange] hybrids produced the smallest plants, 210 days after transplanting (table III)

\subsection{Percentage of plants suitable for grafting}

Only two somatic hybrids, [Caipira sweet orange + Volkamer lemon] and [Rohde Red Valencia sweet orange + Volkamer lemon], reached the grafting stage 210 days after the transplant, with an average of $52.5 \%$ and $50.0 \%$ of plants suitable for grafting, respectively (table IV). Nevertheless, although some hybrids did not show similar results, it does not mean that they do not have positive characteristics in relation to their performance in the nursery and in the field, such as scion budtake, compatibility and vigor.

Regarding average scion and root dry mass, [Caipira sweet orange + Cleopatra mandarin], [Caipira sweet orange + Volkamer lemon], [Caipira sweet orange + Rough lemon], [Cleopatra mandarin + Volkamer lemon] and 


\section{R. Pio et al.}

Table IV.

Percentage of plants suitable for grafting, average scion dry mass and average root dry mass of 11 citrus somatic

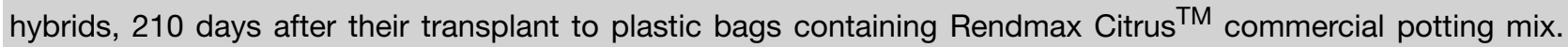
(USP/ESALQ, Piracicaba-SP, Brazil, 2004).

\begin{tabular}{lccc} 
Somatic hybrid & $\begin{array}{c}\text { Plants suitable for grafting } \\
(\%)\end{array}$ & $\begin{array}{c}\text { Average scion dry mass } \\
(\mathrm{g})\end{array}$ & $\begin{array}{c}\text { Average root dry mass } \\
(\mathrm{g})\end{array}$ \\
\hline Rangpur lime + sour orange & $0 \mathrm{~d}$ & $0.6 \mathrm{c}$ & $0.3 \mathrm{~b}$ \\
Caipira sweet orange + Rangpur lime & $0 \mathrm{~d}$ & $3.7 \mathrm{~b}$ & $1.5 \mathrm{a}$ \\
Caipira sweet orange + Cleopatra mandarin & $30.0 \mathrm{~b}$ & $4.9 \mathrm{a}$ & $1.9 \mathrm{a}$ \\
Caipira sweet orange + Volkamer lemon & $52.5 \mathrm{a}$ & $5.9 \mathrm{a}$ & $2.1 \mathrm{a}$ \\
Caipira sweet orange + Rough lemon & $25.0 \mathrm{c}$ & $5.3 \mathrm{a}$ & $1.9 \mathrm{a}$ \\
Cleopatra mandarin + Volkamer lemon & $33.8 \mathrm{~b}$ & $5.5 \mathrm{a}$ & $1.9 \mathrm{a}$ \\
Cleopatra mandarin + sour orange & $0 \mathrm{~d}$ & $1.3 \mathrm{c}$ & $0.7 \mathrm{~b}$ \\
Rangpur lime + Sunki mandarin & $22.5 \mathrm{c}$ & $3.9 \mathrm{~b}$ & $1.7 \mathrm{a}$ \\
Ruby Blood sweet orange + Volkamer lemon & $2.5 \mathrm{~d}$ & $2.3 \mathrm{c}$ & $1.1 \mathrm{~b}$ \\
Rohde Red Valencia sweet orange + Volkamer lemon & $50.0 \mathrm{a}$ & $5.8 \mathrm{a}$ & $2.4 \mathrm{a}$ \\
Valencia sweet orange + Fortunella obovata & $0 \mathrm{~d}$ & $2.0 \mathrm{c}$ & $0.7 \mathrm{~b}$ \\
Coefficient de variation (\%) & 26.3 & 22.8 & 20.9
\end{tabular}

[Rohde Red Valencia sweet orange + Volkamer lemon] hybrids had more mass compared with the others (table IV).

\section{Conclusions}

(1) The somatic hybrids have great rooting potential for cuttings;

(2) [Caipira sweet orange + Cleopatra mandarin], [Caipira sweet orange + Volkamer lemon], [Rangpur lime + Sunki mandarin] and [Rohde Red Valencia sweet orange + Volkamer lemon] hybrids resulted in the formation of many roots;

(3) The [Caipira sweet orange + Volkamer lemon] and [Rohde Red Valencia sweet orange + Volkamer lemon] hybrids had very good development after transplanting.

\section{References}

[1] Grosser J.W., Ollitrault P., Olivarer-Fuster O., Somatic hybridization in Citrus: an effective tool to facilitate variety improvement, In Vitro Cell. Dev.-PI. 36 (2000) 434-449.
[2] Grosser J.W., Gmitter F.G. Jr., Protoplast fusion and citrus improvement, Plant Breeding Rev. 8 (1990) 339-374.

[3] Platt R.G., Optiz K.W., Propagation of Citrus, in: Reuther W. (Eds.), The citrus industry, Univ. Calif. Press, Berkeley, USA, 1973, p. 1-47.

[4] Boava L.P., Siviero A., Masuda Y., Furtado E.L., Machado M.A., Resistência de citrandarins e citranges a Phytophthora parasitica, Laranja 24 (1) (2003) 135-144.

[5] Frost H.B., Soost R.K., Seed reproduction: development of gametes and embryos, in: Reuther W., Batchelor L.D., Webber H.J. (Eds.), The citrus industry, Univ. Calif. Press, Berkeley, USA, 1968, p. 290-324.

[6] Soost R.K., Cameron J.W., Citrus, in: Janick J., Moore J.N. (Eds.), Advances in fruit breeding, Purdue Univ. Press, West Lafayette, USA, 1975, p. 507-540.

[7\} Costa M.A.P.C., Mendes B.M.J., Mourão Filho F.A.A., Somatic hybridization for improvement of citrus rootstock: production of five new combinations with potential for improved disease resistance, Aust. J. Exp. Agr. 43 (2003) 1151-1156.

[8] Mendes B.M.J., Mourão Filho F.A.A., Farias P.C.M., Benedito V.A., Citrus somatic hybridization with potential for improved blight and 
CTV resistance, In Vitro Cell. Dev.-PI. 37 (2001) 490-495.

[9] Mendes-da-Glória F.J., Mourão Filho F.A.A., Camargo L.E.A., Mendes B.M.J., Caipira sweet orange + Rangpur lime: a potential somatic hybrid for use as roostock in the Brazilian citrus industry, Genet. Mol. Biol. 23 (3) (2000) 661-665.

[10] Fachinello J.C., Hoffmann A., Nachtigal J.C. Kersten E., Fortes G.R.L., Propagação de plantas frutíferas de clima temperado, UFPel, Pelotas, Brazil, 1995, 178 p.

[11] Pasqual M., Chalfun N.N.J., Ramos J.D., Vale M.R., Silva, C.R.R., Fruticultura comercial: Propagação de plantas frutíferas, UFLA/FAEPE, Lavras, Brazil, 2001, 137 p.

[12] Ollitrault P., Dambier D., Froelicher Y., Bakry F., Aubert B., Rootstock breeding strategies for the Mediterranean citrus industry: the somatic hybridization potential, Fruits 53 (5) (1998) 335-344.

[13] Sabbah S.M., Grosser J.W., Chandler J.L., Louzada E.S., The effect of growth regulators on the rooting of stem cultures of Citrus, related genera and intergeneric somatic hybrids, Proc. Fla. State Hortic. Soc. 104 (1992) 188-191.
[14] Andrade R.A., Martins A.B.G., Propagação vegetativa de porta-enxertos para citros, Rev. Bras. Frutic. 25 (1) (2003) 134-136.

[15] Pio R., Ramos J.D., Gontijo T.C.A., Carrijo E.P., Coelho J.H.C., Alvares B.F., Mendonça V., Enraizamento de estacas dos porta-enxertos de citros 'Fly Dragon' e 'Trifoliata', Rev. Bras. Agrociênc. 8 (3) (2002) 195-198.

[16] Santos R.F.A., Villas Boas R.M.F., Salibe A.A., Estudos sobre o enraizamento de estacas de citros com aplicação de agentes de efeito hormonal, in: IX Cong. Bras. Frutic., Campinas, Brazil, 1987, p. 387-393.

[17] Pratti P., Mourão Filho F.A.A., Dias C.T.S., Scarpare Filho J.A., Estaquia semi-lenhosa: um método rápido e alternativo para a produção de mudas de lima ácida 'Tahiti', Sci. Agric. 56 (1) (1999) 185-190.

[18] Rocha A.C., Tavares E.D., Sandrini M., Carvalho S.A., Silva L.F.C., Propagação de três espécies de citros através do enraizamento de estacas verdes, Rev. Bras. Frutic. 10 (2) (1988) 31-33.

[19] Janick J.A., A ciência da horticultura, Freitas Bastos, Rio de Janeiro, Brazil, 1966, 485 p.

[20] Hartmann H.T., Kester D.E., Davies F.T. Jr., Geneve R.L., Plant propagation: principles and practices, 7 ed., Prentice Hall, New Jersey, USA, 2002, $880 \mathrm{p}$.

\section{Propagación de híbridos somáticos de cítricos con potencial de uso como porta injerto.}

Resumen - Introducción. Debido al largo periodo juvenil de las plantas cítricas, técnicas de propagación vegetativa deben ser adoptadas con la finalidad de reducir el tiempo de los programas de mejoramiento de las especies cítricas. El objetivo del presente trabajo fue el de estudiar la capacidad de enraizamiento de estacas y desarrollo de plantas de 11 híbridos somáticos cítricos con potencial de uso como porta injerto. Material y métodos. Estacas de $15 \mathrm{~cm}$ de largo, con un mínimo de tres yemas y con dos hojas cortadas a la mitad, de 11 híbridos somáticos fueron inmersos en una solución de IBA por $10 \mathrm{~min}$ y colocadas en bandejas de poli estireno expandido, llenadas con el substrato Plantmax Citrus ${ }^{\mathrm{TM}}$ en cámara de nebulización intermitente. Después de 100 días, se evaluaron el porcentaje de estacas enraizadas y con callo, número medio de raíces emitidas y largura media de las raíces. Posteriormente, las estacas fueron pasadas para sacos de plástico mantenidos sobre bancadas suspensas en estufa. Fueron seleccionadas apenas una brotación por estaca. Durante 7 meses, fueron colectado mensualmente la largura media de la brotación y al final el porcentaje de plantas aptas para la injertilla, masa seca media de la brotación y de la raíces. Resultados y discusión. Se concluye que los híbridos [Naranja Caipira + Mandarina Cleopatra], [Naranja Caipira + Limón Volkameriano], [Limón Cravo + Mandarina Sunki] y [Naranja Rohde Red + Limón Volkameriano] presentaron los mejores resultados para el enraizamiento de las estacas; los híbridos [Naranja Caipira + Limón Volkameriano] y [Naranja Rohde Red + Limón Volkameriano] presentaron los mejores desarrollos después de ser transplantados.

\section{Brasil / Citrus sp. / fusión del protoplasto / esquejes enraizamiento}

